\title{
The "Digital twin". Digitization process from the point of view of a classification society.
}

El "Gemelo digital". Proceso de digitalización desde el punto de vista de una sociedad de clasificación.

DOI: https://doi.org/10.25043/19098642.194

Jaime Pancorbo Crespo ${ }^{1}$
Luís Guerrero Gómez $^{2}$
Javier González Arias $^{3}$

\begin{abstract}
The process of digitalization in our society is undeniable and unstoppable and ships are adapting more and more to this new environment. This offers great advantages, since ships can send/receive all the information on all aspects of their current status (allowing more efficient management during the ship's life and even opening the door to autonomous navigation), but this presents a number of intrinsic difficulties due to their connected state (cybersecurity).

All the above will be developed with a massive sensorization of the ships, which will indicate their condition, going from a reactive maintenance to a predictive maintenance. This requires the figure of the digital twin, which digitally represents the physical reality of the ship, and which will be a single source of information for all actors. This digital twin opens the door to "Digital Classification" by Bureau Veritas, in which traditional 2D plans are no longer necessary, but work is done directly in $3 \mathrm{D}$ on the Digital Twin. Bureau Veritas, as a reference classification society, has adapted to the current situation of the industry, favoring the digitalization process in all its aspects. The objective of this article is to present the current state and foreseeable evolution of the technology leading to the Digital Twin concept, its implications in the design and maintenance of ships, all from the point of view of a Classification Society while exemplifying the digitalization process of a Classification Society in different aspects.
\end{abstract}

\section{Key words: Scanning, Digital Model, VeriSTAR AIMS3D}

\section{Resumen}

El proceso de digitalización en nuestra sociedad es innegable e imparable y los buques se adaptan cada día más a este nuevo entorno. Éste ofrece grandes ventajas, ya que los buques pueden enviar/recibir toda la información de todos los aspectos de su estado actual (permitiendo una gestión más eficiente durante la vida del buque e incluso abriendo la puerta de la navegación autónoma), pero presenta una serie de dificultades intrínsecas por el hecho de estar conectados (ciberseguridad). Todo lo anterior se va a desarrollar con una sensorización masiva de los buques, que indique su estado, pasando de un mantenimiento reactivo a un mantenimiento predictivo. Para ello es necesaria la figura del gemelo digital ("digital twin" en inglés), que representa digitalmente la realidad física del buque, y que será una única fuente de información para todos los actores.

Este gemelo digital abre las puertas a la "Clasificación Digital" por parte de Bureau Veritas, en la que ya no sean necesarios los tradicionales planos 2D, sino que se trabaje directamente en 3D sobre el Gemelo Digital. Bureau Veritas, como Sociedad de Clasificación de referencia, se ha adaptado a la situación actual de la industria, favoreciendo el proceso de digitalización en todos sus aspectos.

El objetivo de este artículo es dar a conocer el estado actual y la evolución previsible de la tecnología conducente al concepto de Gemelo Digital, sus implicaciones en los diseńos y mantenimiento de buques, todo desde el punto de vista de una Sociedad de Clasificación a la par que se ejemplifica el proceso de digitalización de una Sociedad de Clasificación en distintos aspectos.

\section{Palabras claves: Digitalización, Modelo Digital, VeriSTAR AIMS3D}

Date Received: January 14 2019 - Fecha de recepción: Enero 14 de 2019

Date Accepted: February 25 2019 - Fecha de aceptación: Febrero 25 de 2019

\footnotetext{
${ }^{1}$ Naval Engineer. Bureau Veritas Spain and Portugal. Madrid, España. Email: Jaime.pancorbo@es.bureauveritas.com

${ }^{2}$ Naval Engineer. Bureau Veritas Spain and Portugal. Madrid, España. Email: Luis.guerrero@es.bureauveritas.com

${ }^{3}$ Naval Engineer. Bureau Veritas Spain and Portugal. Madrid, Espańa. Email: Javier.gonzalez-arias@es.bureauveritas.com
} 


\section{Introduction}

Since those times (19th century) when Classification Societies worked exclusively on paper plans, a lot of time has passed, which Bureau Veritas has ceased the opportunity to continuously adapt to the information management needs of clients. This new information technology and digitalization process has been implemented in Bureau Veritas in certain aspects that fully confer the characteristics of a Classification Society in the 21st century.

Bureau Veritas' digital transformation began in 2015, leading to concrete projects in 2016 which have crystallized into the new tools available to our clients, and which will continue to evolve, along with the rest of the industry.

The changes involved in the digitization process within the work of a classification society like Bureau Veritas affect both the design and the fundamental inspections and other digital services that help and support both shipyards and shipping companies.

\section{Digital transformation in detail}

Digital transformation is based on the following 3 pillars:

1) Digital services. Digital services include the generation of a "digital twin" of the ship, which includes all the ship's information. This model will be very useful, not only for Bureau Veritas, but also for shipyards in the construction phase and shipowners in operation (facilitating groundings, etc.)

2) Customer experience. We have tried to improve the customer experience through digital certification and an array of specific applications that will facilitate the inspection and maintenance work in order to certify the fleet.

3) Operations. In this case, improvement has focused on enhancing the effectiveness and efficiency of ship interventions and Bureau Veritas' in-ternal procedures.

Table 1 shows in more detail the most fundamental aspects of the digitization process, which can

Table 1. Implementation phases of digitization at Bureau Veritas.

\begin{tabular}{|c|c|c|c|}
\hline & DIGITAL SERVICES & CLIENT EXPERIENCE & OPERATIONS \\
\hline $\begin{array}{c}\text { 1ST } \\
\text { PHASE }\end{array}$ & $\begin{array}{c}\text { Digital Modelling \& and AIM } \\
\text { Veristar AIM } 3 D \\
\text { SMART SHIP } \\
\text { Cybersecurity and advanced } \\
\text { testing }\end{array}$ & $\begin{array}{c}\text { MOBILE APPS } \\
\text { My Veristar } \\
\text { CAN I TAKE THIS PRODUCT? } \\
\text { Veristar Dangerous Goods \& Bulk } \\
\text { E-COMMERCE } \\
\text { My BWMP }\end{array}$ & $\begin{array}{c}\text { CONNECTED SURVEYOR } \\
\text { My Jobs } \\
\text { PLAN APPROVAL } \\
\text { MONITORING } \\
\text { FIT Deadline - FIT Workload - } \\
\text { TABLEAU } \\
\text { E LEARNING }\end{array}$ \\
\hline & \multicolumn{3}{|c|}{$\begin{array}{c}\text { 3D CLASSIFICATION } \\
\text { ADVANCED INSPECTION METHODS }\end{array}$} \\
\hline $\begin{array}{c}\text { 2ND } \\
\text { PHASE }\end{array}$ & $\begin{array}{l}\text { VENDOR ASSESSMENT } \\
\text { Linked to the customer's } \\
\text { purchasing platform } \\
\text { DATA ANALYSIS AND } \\
\text { DASHBOARD } \\
\text { Fleet Performance Indicator }\end{array}$ & $\begin{array}{c}\text { DIGITAL CERTIFICATES } \\
\text { INTERFACE WITH } \\
\text { CUSTOMER'S TOOLS } \\
\text { Plans, Ship Status }\end{array}$ & $\begin{array}{c}\text { ONLINE PLANNING } \\
\text { My Chronos }\end{array}$ \\
\hline $\begin{array}{l}\text { 3RD } \\
\text { PHASE }\end{array}$ & $\begin{array}{l}\text { DIGITAL MODELLING AND } \\
\text { AIM } \\
\text { Veristar AIM 3D - ERP\&DMS } \\
\text { Connection } \\
\text { ADVANCED PANELS } \\
\text { Increased PIF and mobile access }\end{array}$ & $\begin{array}{c}\text { NEW MOBILE APPS } \\
\text { PSC Checklist } \\
\text { My Approval Explorer }\end{array}$ & $\begin{array}{l}\text { CONNECTED SURVEYOR } \\
\text { Complete process on board }\end{array}$ \\
\hline
\end{tabular}


be divided into several phases, which have been implemented at Bureau Veritas in recent years, but all of which are operational today.

In other words, the implementation of the transformation has been done progressively. To describe this large number of developments, we will RELY on these phases:

\section{A) Phase one}

As far as the first phase implementations are concerned and have been in operation for a long time, both for Bureau Veritas and for external clients (shipyards, shipowners and equipment manufacturers), it can be said that the deeper development is already implemented at Bureau Veritas, with several pilots being executed with clients and feeding back the system with their answers, consists of digital modelling, the socalled "Digital Twin", which Bureau Veritas has implemented through the VeriSTAR AIM 3D system, which consists of Asset Integrity Management. This process will be dealt with separately in this article, and will be described in the final part of the article.
Due to the technological advances that have favored automated ship arrangements and are increasingly dependent on communications, together with new software-based technologies (dynamic positioning, electronic systems to optimize consumption, reduction of gas emissions, etc), cybersecurity (and specifically hacking), has made our hardware/software systems one of the possible "weak points" in international shipping, which must be improved and secured. In parallel with the development of the digital twin, and as a second fundamental aspect of digital services, an evaluation of cybersecurity has been carried out, both in aspects related to piracy and those to prevent unintentional accidents, as well as the evaluation of the performance of a software or system. For this, specific collaborators have been sought in each of the aforementioned tasks.

In the following table (Table 2) we can see the different lines of action of Bureau Veritas in the area of cyber security.

It is important to highlight the HWIL (HardWare In the Loop), used to standardize test procedures, reports, etc, of control systems (including

Table 2. Processes related to Cybersecurity at Bureau Veritas.

\begin{tabular}{|c|c|c|}
\hline CYBER SECURITY & CYBER SAFETY & CYBER PERFORMANCE \\
\hline $\begin{array}{c}=\text { Prevention of malicious } \\
\text { voluntary actions }\end{array}$ & $\begin{array}{c}\text { Prevention of unintentional actions, } \\
\text { errors or failures }\end{array}$ & $\begin{array}{l}\text { Performance control of a } \\
\text { certain system or software }\end{array}$ \\
\hline $\begin{array}{c}\text { SYS-COM } \\
\text { New class notation, with TAC } \\
\text { covering remote access and data } \\
\text { exchange in a secure manner }\end{array}$ & $\begin{array}{l}\text { IACS UR E22 \& HWIL } \\
\text { Classification system based on the } \\
\text { criticality of the elements of the system } \\
\text { - Certification of critical systems } \\
\text { - Systems integration }\end{array}$ & $\begin{array}{l}\text { Concordance with } \\
\text { specification } \\
\text { Equipment for remote monitoring } \\
\text { and control }\end{array}$ \\
\hline $\begin{array}{l}\text { Risk analysis consultancy: } \\
\text { - Network } \\
\text { - Software } \\
\text { - Remote access }\end{array}$ & $\begin{array}{l}\quad \text { Test Consulting } \\
\text { - Compliance with UR E22 } \\
\text { - Systems integration. } \\
\text { - Software }\end{array}$ & $\begin{array}{l}\quad \text { Performance Consulting } \\
\text { - CBM (Condition Based } \\
\text { Monitoring) } \\
\text { - Autonomous systems } \\
\text { - Energy efficiency fuel } \\
\text { consumption and emissions } \\
\text { measurement }\end{array}$ \\
\hline
\end{tabular}


monitoring and protection systems) in a simulated environment. The tests will be performed by a third party duly authorized by Bureau Veritas, assigned to those ships having an increased reliability of ship-to-shore communications means, so as to allow monitoring analysis as well as remote troubleshooting, increasing the reliability of the ship and its operations when using automation, support and maintenance systems.

Other tools already in place are, in terms of helping the shipowner to improve the customer experience:

1. Mobile applications (My VeriSTAR). It is an application designed for shipowners. It can be used to track the ship, both in terms of certificates, class recommendations and other information regarding classification.

2. Tools on certain products (VeriSTAR Dangeous Goods and VeriSTAR Chemicals) They can be used to check whether our ship is ready to carry a certain cargo, either of those indicated in the IMDG or in the IBC. It responds to a specific need of the ship-ping companies to verify, in a short period of time, the viability of transporting a cargo that is not in the list of products.

3. E-Commerce. The e-commerce started with the web tool "My BWMP" (Note: BWMP: Ballast Water Management Plan), in which the shipowner can submit a plan for verification, while receiving the quotation online, being able to pay by credit card. This is a further facility for shipowners, especially in view of the dates of application of this manual.

Internally, Bureau Veritas' procedures have been modified, making use of tools such as VeriSTAR Project Management (VPM), which is a tool that facilitates collaboration between shipyard/designer and Bureau Veritas, and also provides possible access for the shipowner and various tools for measuring KPI's (Key Performance Indicators):

1. Linking the number of plans received by each department in the office with the human resources available to them, creating conflict matrices that allow for the identification of subcontracting needs, etc. in advance. This program is known as FIT-WorkLoad (FITWL)

2. In the same way, the KPIs of each department or office are obtained through another tool that monitors the plan approval process. This data can be obtained by project, by inspector, etc., facilitating the management of the whole process. The program that monitors this process is the FIT-DeadLine (FIT-DL).

In September 2017, an internal program was launched encompassing both tools, called TABLEAU.

With regard to e-learning, it affects two fundamental fields:

a) Internally, to the training of Bureau Veritas inspectors. Under the old system of training inspectors, more than 500 New Builders or In-Service Vessel Inspectors were trained each year, which meant about 1600 days of training per year. Currently, and by means of the online training systems, the number of classroom training sessions has been reduced by more than $80 \%$. Online training gives it a versatility and capacity to adapt to the needs of each inspector/inspection area, which would not otherwise be possible.

b) Externally: It is important to point out that Bureau Veritas is increasingly incorporating web based teaching through the Bureau Veritas Learning School, with online courses including ISM, etc. The most recent being the Master's Degree in Ship Inspection, which was conducted entirely in Spanish and was very well received in its first edition.

\section{B) Second Phase}

As far as the first phase implementations are concerned and have been in operation for a long time, both for Bureau Veritas and for external clients (shipyards, shipowners and equipment manufacturers), it can be said that the deeper development is already implemented at Bureau Veritas, with several pilots executed with clients and feeding back the system with their answers, 
consists of digital modelling, the so-called "Digital Twin", which Bureau Veritas has implemented through the VeriSTAR AIM 3D system, which consists of Asset Integrity Management. This process will be dealt with separately in this article and will be described in the final part of the article. In this second phase, several initiatives have been developed that include the long awaited $3 \mathrm{D}$ classification, which will mean not having to send plans for verification, but only a 3D model (which will be the so-called "digital twin") (NOTE: Obviously, there are plans that, due to other regulations, must be available on board, in paper format, at the disposal of the captain: Fault Management Plan and Book, Safety Plan, etc.).

Advanced inspection methods (e.g. visual and thermal inspection with drones), are imposing their utility and assuming within the processes of the Classification Society (with appropriate limitations). The first certification for a drone company has been delivered in the Netherlands in September, with that company (RYMS) operating as a "Service Vendor" of Bureau Veritas (i.e. a company performing class inspections).
To close the circle of the classification process, the certification of the ship will be transformed into digital, which is being developed with pilot experiences together with the Danish and Dutch Maritime Authorities (DMA and NSI). Bureau Veritas inspections may be completed on the ship through the electronic signature of the inspector and verified on a verification website.

This will be complemented by tools that will interact with both:

a) Shipyard. Through the already used VeriSTAR Project Management (management tool for the approval of plans and comments, implemented in Spain in all the shipyards since 2012), it will link with the shipyards' plans management systems,

b) Shipowners: The interconnection with the shipowner's systems will be carried out, especially in order to know the state of the ship, regarding its class certification and visits.

Internally, it has been implemented from the "My Chronos" program, which is another App

Fig. 1. Bureau Veritas inspection planning tools.

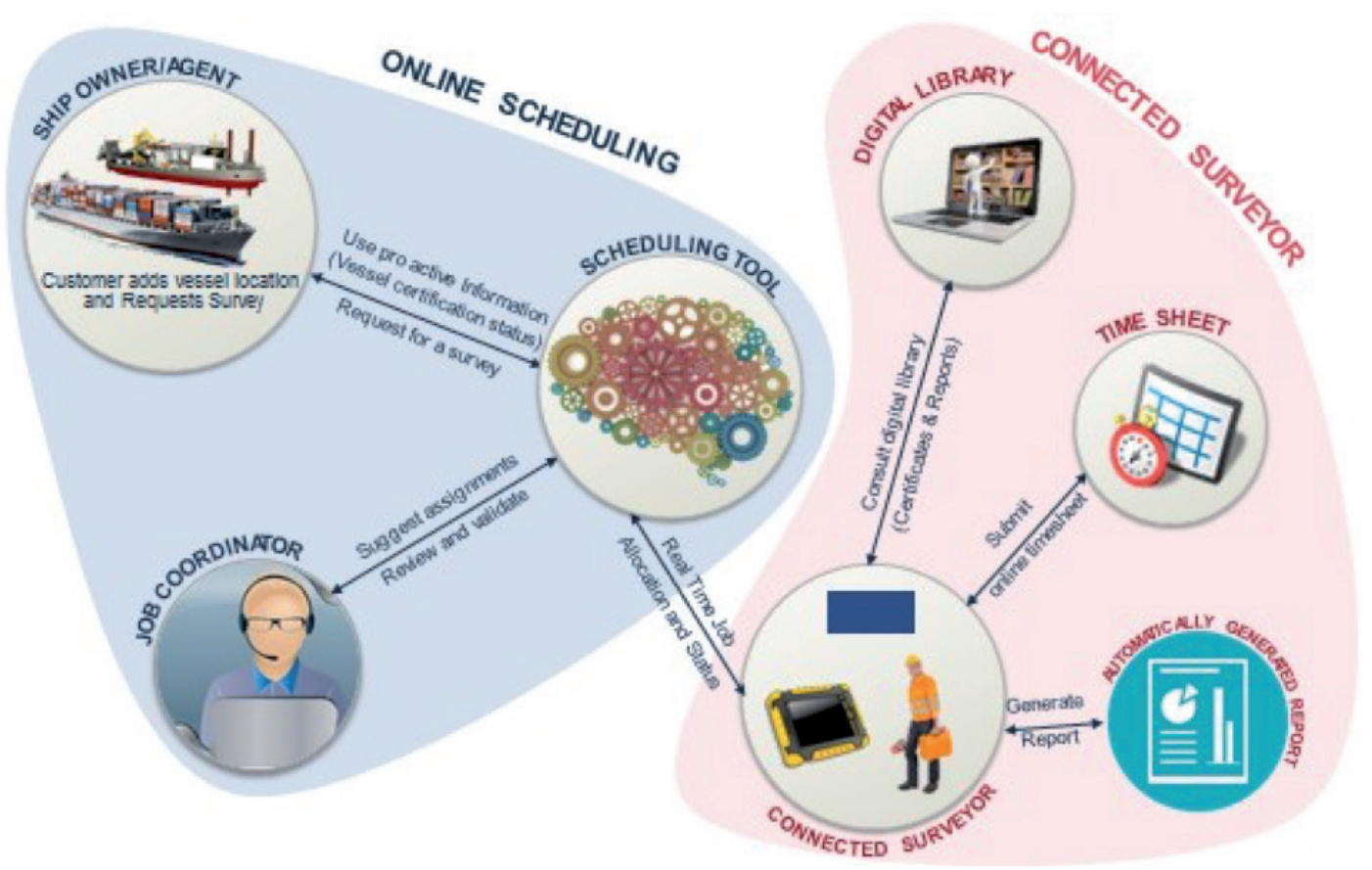


that is used by planners, in order to optimize the resources of the Company giving the best possible service to the shipowner when a visit is requested. This inspection request will be managed by an inspection coordinator, who through this planning tool (My Chronos) will give the order to the inspector, who will be able to carry out the inspection and issue the corresponding certificates. In order to correctly explain how Bureau Veritas' tools work in the field of inspection planning, Fig. 1 explains the process to be followed.

\section{C) Third Phase}

The initiatives in this third phase involve, firstly, connecting the digital model with all the CAD systems on the market, through a "neutral" platform that can be fed with the models generated in the various systems and can be exported to them. Currently these "links" are already made for some software, but not for all, due to the great variety of existing design programs.

A development mainly for the use of shipowners will be the possibility of generating personalized dashboards with the most significant data that the owner of a certain vessel or fleet wants to present.
One of the most important innovations is the FPI (Fleet Performance Indicator), i.e. an internal indicator that considers ship recommendations, detentions, etc., so that a comparison can be made between ships in the fleet. An example of the above-mentioned PIF can be seen in Fig. 2.

More initiatives under development and that will reach the Classification Society are the use of virtual reality (VR) and augmented reality, whose integration into the usual use of the sector is not a question of if but when it will be done.

But let's focus on the digital twin and the environment in which AIMS-3D is contemplated.

\section{VeriSTAR AIMS 3D}

The AIMS 3D system aims to generate the "digital twin", which is nothing more than the digital representation of a physical model (in this case, the ship). This model will represent all the data from the physical vessel, and will be fed back through sensors and direct data input.

This model will serve in the development of the project during the new construction and

Fig. 2. Fleet Performance Indicator (FPI).

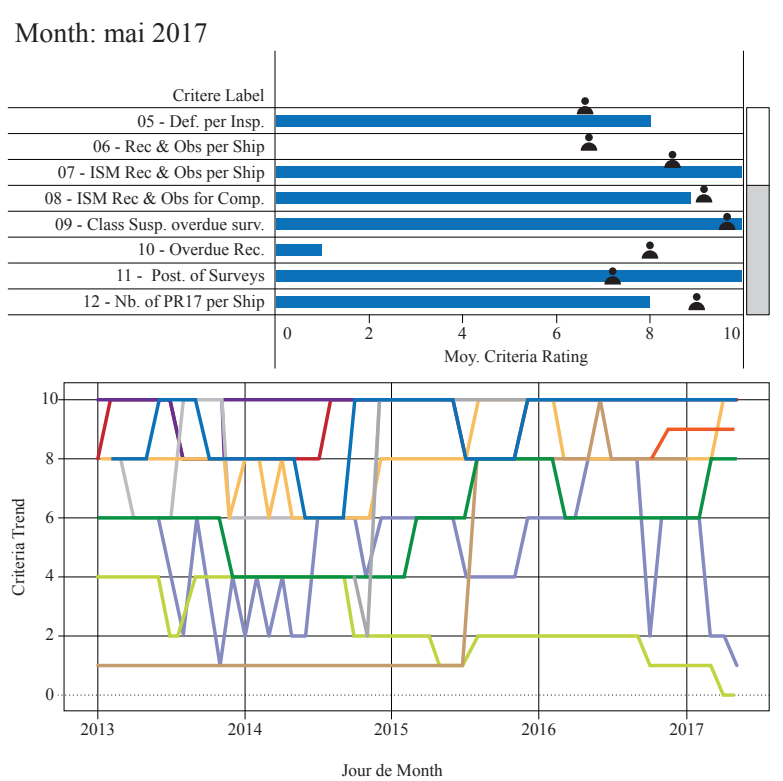

Month: mai 2017

Global Performance Index BV: 80,876

Global Performance Index: $\quad 85,250$

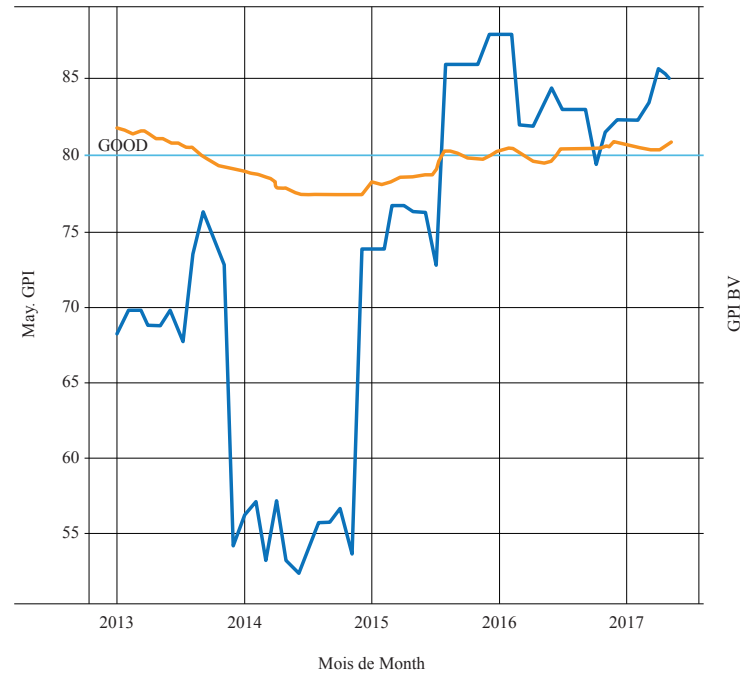


the maintenance of the ship during its life in service, covering the needs of both shipyards and shipowners.

The most important part and the one that started the development is the one corresponding to the generation of the model and the structural calculation. For this purpose, different CAD systems have been evaluated, in order to interact with existing Bureau Veritas programs, and finally, the decision has been made to collaborate in the development of a tool with the French company Dassault Systems, whose system, known as CATIA 3D EXPERIENCE, is already well established mainly in the aerospace and automotive sector.

In the first phase, work was carried out on the interaction with Bureau Veritas software regarding structure, stability and performance at sea, as can be seen in the following graph, relating the digital model to the various internal Bureau Veritas programs:

Fig. 3. Digital Twin: Single Data Source for Many Programs.

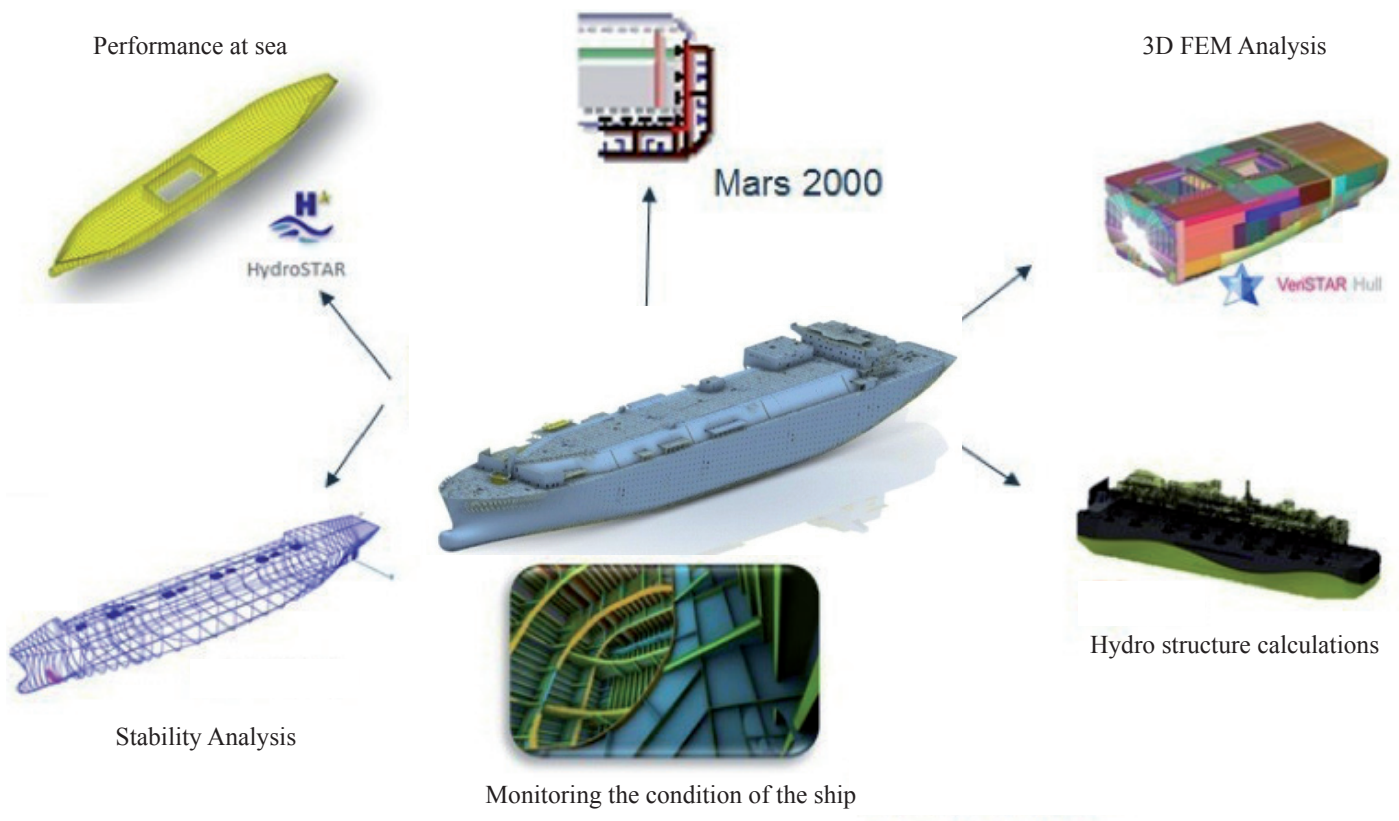

To prepare the model, the software allows the Fig. 4. LNG template. direct generation of the model, as well as the use of templates, which are already made for complete ships (classified by ship type: tankers, bulk-carriers, LNG, LPG, etc.), as well as for particular elements (e.g.: bulkheads, lower and upper hoppers, as well as other elements of the complete generated library)

In a parametric way, these templates allow a fast and effective recreation of the ship, reducing the time needed to generate a model and avoiding possible errors due to inconsistencies between plans with different revisions, since the model is unique and all actors will feed from it. An example of a template is the following, which is a template for a membrane LNG carrier:

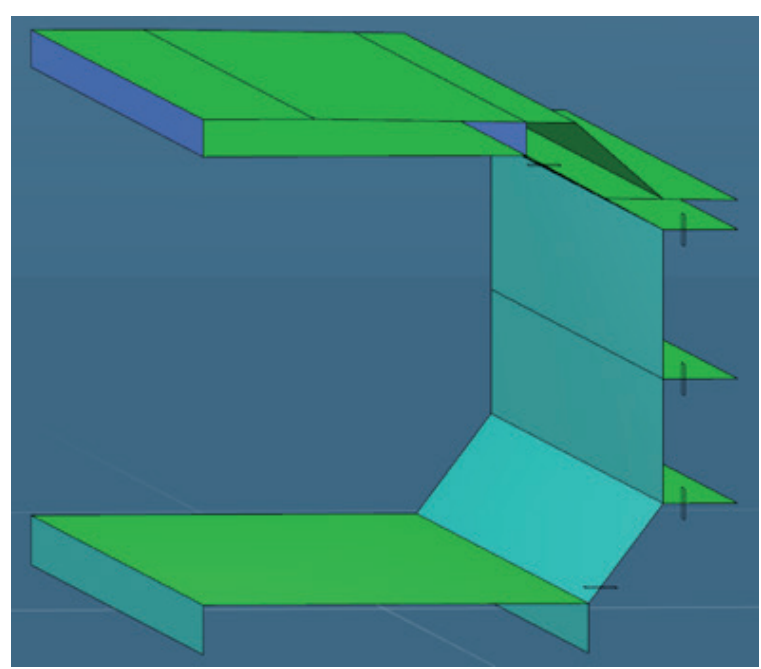


The templates will also help us in the most complicated areas to make the model and which are the most time consuming, such as the final holds and the bow and stern ends, as you can see in the following image, as well as a template of one of these holds/end tanks:

Fig. 5. Model of a bow hold (along with the rest of the bow) and one of the templates of a bow tank.
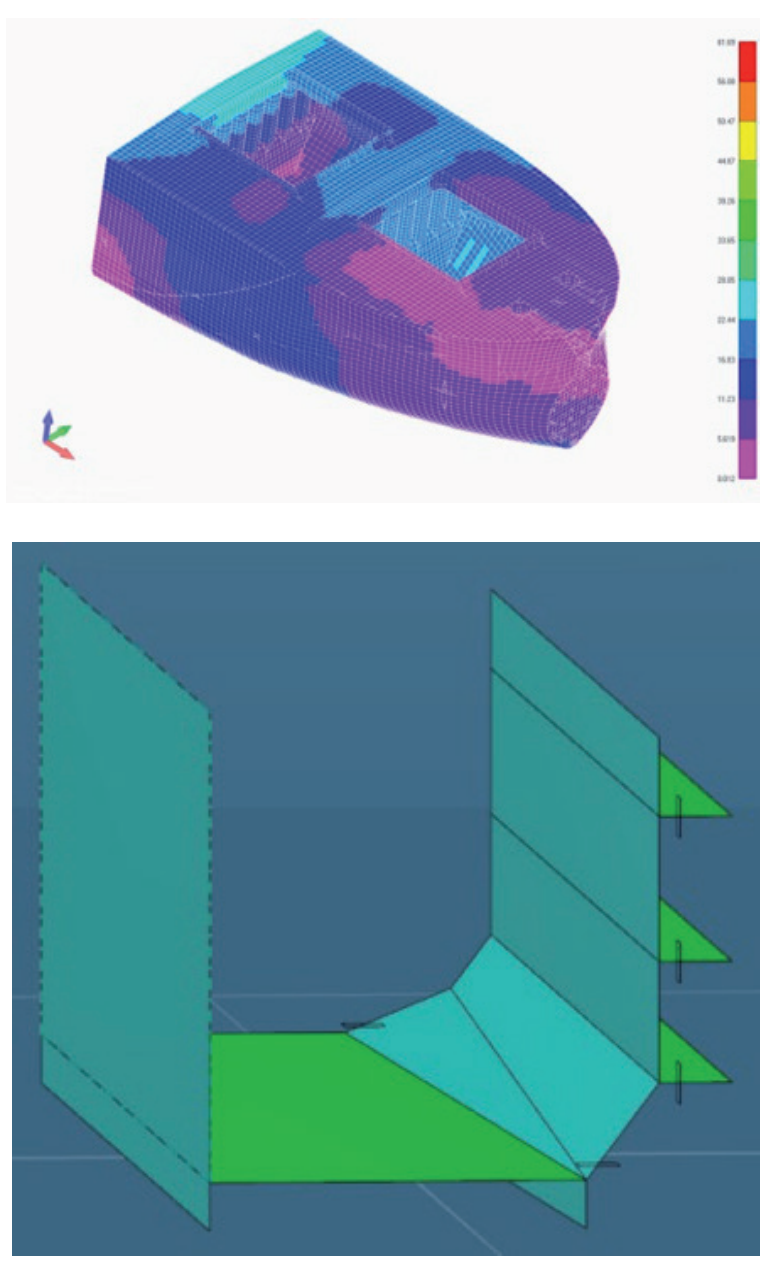

Once the model is generated, and focusing on the structural aspect, the meshing is almost immediate, with the consequent simplification in the whole verification process. Once the model is generated, this structural model is automatically imported into VeriSTAR Hull, Bureau Veritas' finite element program, which will handle the resolution and post-processing (performance evaluation).

The comments resulting from the review will be included directly in the 3D model, which can be monitored and will be available to both Bureau Veritas inspectors and the shipyard (and eventually the shipowner), as is currently the case, but with $2 \mathrm{D}$ drawings.

A very important aspect of the model is that it is collaborative, wanting to indicate that all the actors involved can participate in the feedback of the model (obviously, the data needed by one and another participant in many cases are not the same). For example, Bureau Veritas inspection reports will go directly into the model, incorporating their results into the model, both in terms of thickness measurements, areas where cracks have been detected, etc. All this will allow the creation of a model that will not only be useful in the production process of the ship, but will also accompany it throughout its life in service.

Given the different needs of the different Classification Society, Shipyard and Shipowner Inspectors, a more simplified tool (a 3D model viewer) will be provided to allow all the participants to see the digital model together with all the information it contains, with a simple handling (i.e. no mesh generation, etc). We are currently working with a platform called SmartShape.

All these data will be integrated into the platform in such a way that they form a "Smart Data", i.e. data presented in a way that facilitates and assists decision-making, both in the design phase and in the service life phase of the ship.

Another substantial advantage is the access to information: all of it (status, indicators, information about visits, etc.) can be accessed from the network theough mobile/tablet apps, giving a flexibility and robustness in the information that could not be given until now. The "dashboard", represents in a graphic and simple way all the parameters that we want to know about the ship or fleet (See Fig. 6).

In addition, the AIMS 3D tool has other functionalities, which are very useful for specific purposes: 
Fig. 6. Internet access and dashboards.

NETWORK ACCESS AND DASHBOARDS

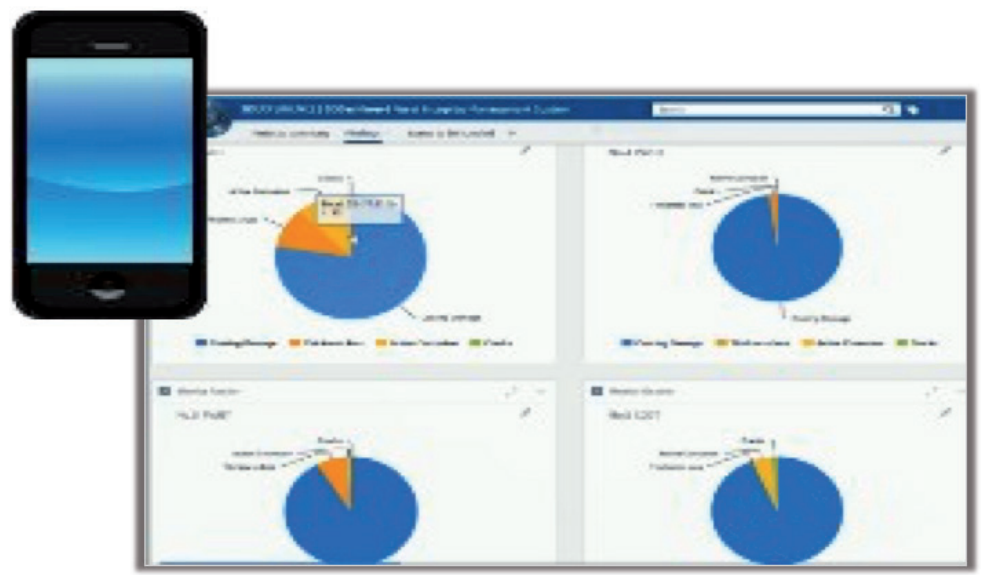

\section{Offline work mode.}

This way of working allows to make modifications on the model that has been previously downloaded in our computer, and once the conditions to establish a connection are restored, to overturn this data in our model. Initially it was approached solely for training purposes, so that inspections could be planned on the "digital twin", in order to increase the efficiency and effectiveness of the intervention on the physical vessel. Subsequently, the benefits that this functionality has for the information feedback (mainly from the shipowner) and the subsequent uploading on the model, have resulted in the development of specific applications, considering the internet unavailability (or sufficient bandwidth) to work directly with the model and having to do it offline mode.

\section{Interaction with the client's IT systems.}

The virtual model generated will be able to have interactions with the main management tools of our clients, mainly with

a) CMSS (Computerized Maintenance Management System)

b) ERP (Enterprise Resource Planning)

c) DMS (Document Management System)
In other words, it not only deals with document management, but also with planning and maintenance.

As an example, to summarize, the advantages of using the digital model in the classification process, for a shipowner, throughout its life, the process would be as follows:

During the construction phase of the ship, the database will be created and all the necessary interconnections will be made, both with all Bureau Veritas tools and with those of the client, so that when the ship is operating they will be operational. Once in service, the process for conducting class visits is simplified as follows:

The shipowner will be alerted on his mobile phone/ computer (App My VeriSTAR) that the deadline for a visit is approaching according to the preferred notices, the shipowner will request the visit (time and place) on this same tool (My VeriSTAR), and that information will arrive in real time at Bureau Veritas. Bureau Veritas will look for the best possible inspector, with the necessary accreditations given the type of ship and according to the shipowner's request for date and place (Online Scheduling/ My Chronos), and the work order will be given 
to the inspector, via the mobile phone (My Jobs). The inspection will be carried out on board, either in a conventional way or with new inspection systems (drones and others), and reports will be made through the same tool (My Jobs), receiving the Digital Certificate, with the consequent saving of time in the inspection. If necessary, the measurements taken on the ship (e.g. thickness), would go to the digital twin which will make a recalculation of the structure of the ship as well as any other study considered necessary, giving the corresponding recommendations, thus optimizing the renovations, etc. and in the same way, it will incorporate all the notes of the inspector, issuing immediately the inspection reports with the digital seal. All this would be integrated together with the shipowner's tools, so that it would be much more comfortable for him to plan the groundings and the necessary work in each one of them.

\section{Conclusion}

We can summarize that Bureau Veritas' digitalization process has been adapting to the new needs of the 4.0 industry, focusing both on internal processes and on the interaction with clients, through new tools, among which the generation of the "digital twin" stands out, which will allow following the life of the ship from its design stage throughout its useful life.

Regarding the inspections to be carried out, Bureau Veritas has evolved in the two aspects that make up this field.

a) The request for inspections and subsequent feeding of the digital twin with this data b) The inspection itself, using the new inspection methods available in our industry (drones, etc).

It should be noted that these inspections will be increasingly risk based $(\mathrm{RBI}=$ Risk Based Inspections), which are managed through specific risk analysis programs that evaluate the frequencies (probability of occurrence) and severity of the damage, generating a risk matrix that can be used to plan equipment reviews according to this index, optimizing visits and allowing for planning.

This is the first step in Bureau Veritas' ongoing digitalization, the ultimate goal of which is to be fully aligned with our clients' tools and methodologies, while offering an increasingly efficient and effective service.

The digital era has begun, as a collaborative era in which new technologies are asserting themselves and Bureau Veritas has adapted and will continue to adapt both its internal processes and methodology to the progress of the industry.

\section{References}

1. Bureau Veritas NR467 Rules for Steel Ships, July 2018.

2. Bureau Veritas presentations in the years 20172018. 